\title{
THE LAST OF THE MOHICANS AS A NATIONAL MONUMENT
}

\begin{abstract}
Monuments are usually associated with size, which befits the renowned American fascination for big proportions. The colonization of America, however, owes a lot to its idealized concept as a virgin land, devoid of history and of the monuments that typically symbolize the latter. Vast tracts of American land are officially treated as national monuments; just like architectural constructions dedicated to the celebration of national pride and identity, the natural environment is emblematic of the essence of the country. This article establishes that The Last of the Mohicans too may be seen as a national monument which aims to express the quintessence of the United States, as well as a memorial - in a potentially subversive way.
\end{abstract}

Key words: American, Cooper, monument, memorial, nostalgia

\section{Introduction}

The plot of The Last of the Mohicans is set in 1757 in New York State, during the French-English war. The two daughters of Colonel Munro, the commander of the British troops, want to join their father a few miles north. Alice is blonde and fragile. Cora is dark-haired and resilient; her mother was a mixed-race woman. It is a dangerous journey across Indian territories, for some tribes were British allies, while others sided with the French. The two women are escorted by some men, notably Chingachgook (a Mohican), his white friend ("the scout") and Heyward (a young American officer). On the way, Alice and Cora are abducted by Magua, the Huron villain, and the end of the novel depicts the final confrontation between Magua and the young Uncas, the son of Chingachgook. The 1826 introduction sets the reader in a postapocalyptic universe, holding that the Mohicans are now extinct.

Monuments are usually associated with size, which befits the renowned American fascination for big proportions, commensurate with the size of the country. The colonization of America, however, owes a lot to its idealized concept as a virgin land, devoid of history - and of the monuments that typically symbolize the latter. Webster's defines "monument" as "any building, megalith, etc., surviving from a past age, and regarded as of historical or archaeological importance" .

\footnotetext{
* Université Grenoble Alpes, France, Bâtiment Marguerite Soubeyran - 87, avenue de Romans, 26000 Valence, France; email: frederic.dumas@univ-grenoble-alpes.fr

1 “Monument", Random House Webster's Unabridged Dictionary (1999).
} 
One notable American particularity is the fact that vast tracts of land are officially treated as national monuments, thereby considering that, just like architectural constructions dedicated to the celebration of national pride and identity, the natural environment is emblematic of the essence of the country. In this context, The Last of the Mohicans may be seen as a national monument, a vessel for national characteristics supposed to express the quintessence of the United States ${ }^{2}$. The novel is undoubtedly a romantic monument to the values embodied by the characters, which sets it in a prestigious literary tradition: "the novel does have the epic theme of the death of a nation" (Rans 1991: 127). Following the same logic, Porte states that "The Last of the Mohicans, like the Iliad, celebrates the heroic virtues of individuals against a background of general social disintegration" (1969: 41). Dekker also provides convenient definitions of "epic" that apply to The Last of the Mohicans, which composes a "proper narrative [...] suitable for treating 'heroic matter', as well as "the portrait of a 'whole' community" and "the most inclusive narrative, capable of containing romance" (1987: 55).

As a reminder of some notable historical landmark, a national monument will celebrate human presence and activity. When put together, all such monuments make up a national mythology at the service of the dominant ideology. In that respect, The Last of the Mohicans is an ambiguous creation, for it also fulfills the role of a memorial ("something designed to preserve the memory of a person, event, etc.") ${ }^{3}$ in a potentially subversive way.

\section{2. $L M$ as a war memorial}

As a historical romance, The Last of the Mohicans fictionalizes history and historicizes fiction. As "A Narrative of 1757" (Cooper 2008: 1), it is centered on the defeat of the Anglo-Americans at Fort William Henry in 1757, which is a symbolic moment in the birth of the United States. When the book was written, the country had become independent after much more fighting and the English, who stand as the victims in The Last of the Mohicans, had then become the enemy.

Given its title, The Last of the Mohicans does not claim to be about the advent of the American nation, nor is it about the end of English domination. The title looks like an epitaph, which makes the book a mortuary monument dedicated to the "Last of the Mohicans" - i.e. either Uncas or Chingachgook. Since we are not given the name of that person, it is meant also to be taken as a tribute to all the Mohicans, whose essence is expressed in an anonymous individual. The latter would fulfill the role of

\footnotetext{
${ }^{2}$ Roudeau considers that Cooper "monumentaliz[es] the national" in his romances.

3 “Memorial", Random House Webster's Unabridged Dictionary (1999).
} 
the Unknown Soldier, for both Uncas and Chingachgook were warriors. As an epitaph, the title recalls the whole historical period that surrounds the death, with an implied celebration of the values embodied by the deceased. His/her death marks a landmark for the entire community: a symbolic birth. Since the 1831 introduction states that the Mohicans have now all disappeared, the epitaph will be read and should be heeded by the survivors, that is, all (white) Americans, who are to be considered as the fictitious implied readers.

The historical background of the plot is the troubled times that were to eventually give birth to the American republic. One may expect that the message of the literary monument will eulogize the last Mohican warrior in order to extol the virtues of the new country. The 1826 Preface establishes, however, that the United States actually rose from the ashes of Indian civilizations that had reached full political maturity: they were "in truth, the oldest United Republics of which the history of North America furnishes any evidence" (Cooper 1826: 5). The Mohicans, who are made to subsume all Indian nations - including their enemies in the novel - were "United republics" way before the whites conquered their lands and before the invaders even conceived the "United States of America". The Mohicans/Indians as Republicans makes them the political ancestors of the young American republic in 1826, on an unexpected equal footing with the leading figures of the European enlightenment.

Celebrating the memory of the last of the Mohicans amounts to celebrating a bygone era of beginnings; given the absence of written language ${ }^{4}$, Indian historiography did not exist, so from a European type of logic — that of a white American - the Mohican era was the prehistory of the country. The concept of America as the new Promised Land necessarily involved a peculiar outlook on the Natives, torn between assimilating them both to vanishing ghosts of pre-Adamic times and to hellish creatures.

By making the Mohican the epitome of the "good" Indian (who, in those days was the one who helped the Anglo colonizers), The Last of the Mohicans turns the Mohican into a "monument": "a person considered as a heroic figure or of heroic proportions"s. The irony being that this monument is, as always, erected by the victors, who in this case are directly responsible for the death of the very Aborigines they are commemorating. It is not so much hypocrisy as the expression of sublimated guilt that was assailing many white Americans in those days. The Last of the Mohicans undeniably echoes the equivocal attitude of its times: "Cooper reaffirmed a racial ideology tortured with its own historical ambiguities. Written in 1826, at a specific historical moment when the Indian tribes were being removed or destroyed, the novel's

\footnotetext{
${ }^{4}$ First of its kind in North America, the Cherokee syllabary was devised only in the 1820s.

5 "Monument", Random House Webster's Unabridged Dictionary (1999).
} 
anxious ambiguities - its tensions and ambivalences - reflect the contradictions and ambiguities of Cooper's American culture" (Blakemore 1997: 57).

The Mohican is the official hero of the romance also because he shares with white Americans his ambivalent status as a victim and a perpetrator of the wars waged in New York by the European powers, notably the Dutch, the English and the French. His literary tomb also testifies to the cost of American emancipation: the Dutch had relinquished their hold in 1664, and 1757 was at the heart of the French and Indian War. The Last of the Mohicans is full of proleptic references to the end of French and English influence in the region: "It was in this scene of strife and bloodshed, that the incidents we shall attempt to relate occurred, during the third year of the war which England and France last waged, for the possession of a country, that neither was destined to retain" (Cooper 2008: 17). It also mentions the upcoming demise of Montcalm ${ }^{6}$ (Cooper 2008: 174), as well as that of Munro.

The Last of the Mohicans makes it clear that each man stands for the hegemonic policies of his own country, and that the reign of European powers over America was soon to be over. It displays a strong anti-British stance:

The imbecility of her military leaders abroad, and the fatal want of energy in her councils at home, had lowered the character of Great Britain from the proud elevation on which it had been placed by the talents and enterprise of her former warriors and statesmen. No longer dreaded by her enemies, her servants were fast losing the confidence of self-respect. In this mortifying abasement, the colonists, though innocent of her imbecility, and too humble to be the agents of her blunders, were but the natural participators. (Cooper 2008: 17)

Britain's "fatal want of energy" is evocative of the classic American conception of a corrupted Europe: it is a death-like stasis that associates Britain with decay. As for its "imbecility", the term is probably used in its archaic meaning of "weak", though it remains open to ambivalence: in the middle of the eighteenth century, the term also referred to mental feebleness - it fits into a classification that included an adult above an idiot but lower than a moron. Personified Britain is thus shown as sick from within and poorly represented from without. Munro is a case in point: though not mentally deficient, the former flamboyant leader of men quickly becomes a millstone around everybody's neck. His imminent death is foreshadowed by his sudden loss of power and his helplessness at rescuing his daughters. His fall renders natural the symbolic

\footnotetext{
${ }^{6}$ Montcalm died at the battle of the "Plains of Abraham" in 1759 and from then on the French influence waned.
} 
rise of Virginia-born Duncan, who belongs to "the colonists" and represents the new American elite. As an epigraph, "The last of the Mohicans" obliquely heralds the dawn of the next - American - era.

\section{A monumental scope}

\subsection{Monumental heroes}

Most characters are endowed with exceptional qualities, which make them akin to tragic and mythological heroes. They fit the definition of the epic hero put forward by Lukacs: "The epic hero is, strictly speaking, never an individual. It is traditionally thought that one of the essential characteristics of the epic is the fact that its theme is not a personal destiny but the destiny of a community" (1971: 66). The following examples embrace very different types of characters.

Montcalm, who masterminded the Anglo-American defeat, is pictured as a complex figure in the light of history and as a tragic figure at the beginning of Chapter 18, with its epigraph from Othello: the luster of his victory at Fort William Henry is blighted by his weakness towards Magua: "thousands, who know that Montcalm died like a hero on the plains of Abraham, have yet to learn how much he was deficient in that moral courage, without which no man can be truly great" (Cooper 2008: 204). Through him, Britain is not the only European power that is not equal to the task of conquering America. Unlike Munro, who was simply powerless during the massacre perpetrated by Montcalm's Indian allies and becomes a mere passive, pathetic character, Montcalm's failure grants him a paradoxical tragic status: the size of his failure is definitely up to that of the historical moment. He "died like a hero", not as a hero, but still maintained some of his aura as a general (just as, despite his murderous flaw, Othello remained a great general).

Magua, the villain himself, often associated with Milton's Satan and to Shylock, cumulates the qualities of such famed strategists and political masters as Machiavelli and Julius Caesar (Chapter XXVII). The way he motivates his troops before battle makes him an Indian Napoleon (Cooper 2008: 320) and his rhetorical skills a latterday Huron Mark Antony: taken from Shakespeare's Julius Caesar, the epigraph of chapter XXVII (Cooper 2008: 313) celebrates the performative power of language at historic moments.

Even the cowardly Huron achieves tragic grandeur at the moment of his execution, which finally transforms him into the warrior he is expected to be: "As the weapon passed slowly into his heart, he even smiled" (Cooper 2008: 276). Such a transfiguration is akin to that of the Bard's Richard II, who became the great king he had failed to be only at the moment of his death, which he confronted bravely. As the 
very first epigraph of the novel, a quotation from Richard II (Cooper 2008: 15) had paved the way for such telling metamorphoses.

The text similarly provides interpretative clues as to David Gamut. Despite being "the namesake of the Jewish Prince" (Cooper 2008: 96), he is the ridiculous figure of the novel who, only through confrontation with danger and otherness eventually attains some greatness as he finally decides to use a sling against his enemies ("[ $t]$ hough not a vaunting and bloodily disposed Goliah", Cooper 2008: 368).

Unlike these faulty heroes, Uncas, originally the true Last of the Mohicans, displays a stature commensurate with the grandeur of the epic; the perfection of his body and of his mind undeniably makes him "an Indian Appolo" (Dekker 1987: 94).

\subsection{A monumentalized American novel}

The grand scale of the landscapes, along with characters larger than life fighting against a portent historical background, point to a totalizing narrative ambition characteristic of myth, epic and tragedy. Critics have noted the numerous analogies between The Last of the Mohicans and some founding texts, which provide an apt structural guideline:

[T] he framework of the book is [more] clearly derived from the Iliad. Cooper's world is divided between wily Greeks and noble Trojans (Mingoes and Delawares), and the action concerns itself with a coveted woman (Cora). Magua is specifically associated by Cooper, through epigraphs taken from Pope's Iliad, with the Greek leaders (both Achilles and Agamemnon); and the last chapter of the book, in which Chingachgook/Priam, along with the remaining members of his tribe, celebrates and mourns the death of Uncas/Hector, is obviously patterned after the twenty-fourth book of Homer's epic, the funeral of Hector. (Porte 1969: 40)

Cooper's ambivalent attitude towards the Natives makes his ideology complex. Not all Indians are villains, yet they are all bound to disappear so as to make way for the descendants of Heyward and Alice. To Lukacs, Cooper achieves coherence by granting tragic significance to all tribes, and ascribing clear-cut differences between them: some embody evil, others good (basically, the Mohicans and the Delawares). Among the tribes, extraordinary individuals stand out so as to embody the essence of the tragic crisis: 
Cooper's artistic interest is centered on the portrayal of the tragically declining gentile society of the Redskins. With truly epic grandeur Cooper separates the two processes of tragic decline and human and moral classuprooting. He confines the moving tragic features or decline to a few, great surviving figures of the Delawar [sic] tribe, the symptoms of the Indians moral disintegration are represented in breadth and detail in the hostile tribes. This admittedly simplifies his portrayal but in parts gives it an almost epic-like magnificence. (Lukacs 1962: 64)

Cooper also owes a lot to Walter Scott (1771-1832), who fictionalized the making of Great Britain. Scott's defeated eighteenth century Highlanders provide an apt basis for Cooper's Indians; in both cases, literature is a tool to fashion a national history. The monumental aspects of The Last of the Mohicans also lie in its capacity to absorb the nationalist power of Scott's writing in order to put it to its American use, the irony being that what has become one of the most emblematic American Romances should actually derive some of its Americanness from a British tradition. The national facet of our topic emphasizes the role of The Last of the Mohicans in the construction of a specifically American literature: just as in the diegetic America of Cooper's romance Britain and France were striving to gain/keep control of the New World, Europe was to be overcome in the world of letters. In 1826, American literature was still in its infancy: The Last of the Mohicans was necessarily relying on Europe to provide it with a stable substratum from which to build its differences. Critics have noted the great number of intertextual echoes that pepper the novel and many of them resent what they consider as a clumsy imitation of European style?

Awkward as it may sound at times, Cooper's diction is often evocative of Shakespeare, which contributes to monumentalizing his prose. As Munro is agreeing to meet Montcalm following Heyward's parley with the French general, the dialogue clearly displays its debt to Elizabethan drama:

I will meet the Frenchman, and that without fear or delay; promptly, sir, as becomes a servant of my royal master. Go, Major Heyward, and give them a flourish of the music, and send out a messenger to let them know who is coming. We will follow with a small guard, for such respect is due to one who holds the honour of his king in keeping; and hark'ee, Duncan,' he added, in a half whisper, though they were alone, 'it may be prudent to

\footnotetext{
7 "Cooper's literary Offenses" is one of the most ruthless indictments of Cooper's antiquated diction. Mark Twain pokes fun at The Last of the Mohicans ("Cooper's word-sense was singularly dull") and of The Leatherstocking Tales in general: English in The Deerslayer, for instance, is "a crime against the language".
} 
have some aid at hand, in case there should be treachery at the bottom of it all. (Cooper 2008: 182-3)

The archaic wording, prosodic care and dramatic setting imparts an air of solemnity; Cooper tends to resort to Elizabethan-sounding prosody and diction at formal moments, which situates his text within a most prestigious English tradition and endows it with literary respectability. Conjointly with the epigraphs, such verbose and antiquated style contributes to monumentalizing his work.

\subsection{The role of the epigraphs}

Webster's defines the epigraph as: "an inscription, esp. on a building, statue, or the like"s. Such a presence is suggestive of a comment on the frontispiece of a massive textual architecture, devoted to some high purpose. Most of the time in The Last of the Mohicans, the epigraphs provide an analogy with the action: they are illustrative of what is to follow in the next pages and have a proleptic role: by seeming to disclose the gist of what is about to happen, they create a suspense that contributes to the feeling of never-ending or sometimes breathtaking action. Of course, superficial readers will skip the epigraphs, as well as the introductions and the appendices, that is, all that Genette (1969: 5) defined as the peritext. Attentive readers, on the contrary, will be teased by the quotations, whose meaning may only be fully understood in the course of the reading. Sometimes the relationship between the epigraph and the text that it is supposed to shed light on is cryptic. To Genette, "the use of an epigraph is always a mute gesture whose interpretation is left up to the reader. [...] The attribution of relevance in such cases depends on the reader, whose hermeneutic capacity is often put to the test" $(1969: 156,158)$. The intellectuality created by presence of the prestigious works or names that lend literary support to the upcoming narration does not necessarily involve a strictly intellectual response. Genette quotes Stendhal about this aspect: "The epigraph must heighten the reader's feeling, his emotion [...], and not present a more or less philosophical opinion about the situation" (1969: 159). Genette deduces that "[t]his evasive function, more affective than intellectual and sometimes more ornamental than affective, may indeed be assigned to most epigraphs of the type that, to save time, we will call romantic" (1969: 159). Cooper's insistent use of Shakespeare is characteristic of "The romantic period [which] took many epigraphs from Scott, Byron, and especially Shakespeare, [...] (who probably holds the world's record for number of times quoted in epigraphs)" (1969: 159).

The monumental character of the novel, then, is achieved through its historical, mythical and romantic scope, as well as through intertextual echoes that may not

\footnotetext{
8 "Epigraph", Random House Webster's Unabridged Dictionary (1999).
} 
always be grasped by the reader (in that case, the creative genius will be attributed to Cooper). But monumentalization is also a conspicuous process: epigraphs are metatextual elements that reveal the precise nature of their impressive intertextuality. The reader cannot miss the filiation of the following passage; the repetition of the same device at the frontispiece of each chapter creates an identifiable stylistic scheme which contributes to anchoring $L M$ in a doubly prestigious line: the plural one related to Shakespeare, Milton, Pope and the like, and the Romantic - i.e. European - tradition, which relied on the same process and the same authors. Cooper's epigraphs contribute to making a monument of his work, which celebrates a diegetic, American universe and plays a pivotal role in the construction of a national myth. If we endorse Genette's cynical view, we too may reach the conclusion that, by the same token, Cooper is also building his own shrine: "The epigraph in itself is a signal [...] of culture, a password of intellectuality. While the author awaits hypothetical newspaper reviews, literary prizes, and other official recognitions, the epigraph is already [...] his consecration. With it, he chooses his peers and thus his place in the pantheon" (Genette 1969: 160).

\section{A fissured native monument}

\subsection{A challenged aristocracy}

Slotkin notes that Cooper is in tune with a prominent American conception of elitist politics: "The Cooperian status system [...] accords quite well with Jeffersonian theory, which held that while one might find some 'natural aristoi' among the common people, on the whole the existing aristoi would 'breed true': equality in principle reproduces traditional inequalities in fact (1985: 103). "It is true that the scout's authority over Heyward Duncan, who represents the aristoi, is only temporary: it lasts only in the context of Indian warfare, in the wilderness, which is a battlefield the Virginian is forced to admit he knows nothing about. In the end, however, Heyward is made to embody the future of white America by winning Alice, who stands for the romantic reward. Heyward fits Cooper's conception of the aristocrat as "officer and gentleman" (Slotkin 1985: 104) but he is a flat character; the scout is the one who engrosses our attention. To Slotkin, "It is as if Cooper's novelistic instinct for the interesting character were at war with his social conscience" (1985: 104).

The Last of the Mohicans leads one to wonder whether the power of literary/ poetic creation might be stronger than ideology, as if the nature of America, from that of dream, had now become textual. Its complexity is to be explored mostly by hermeneutics, which must take into account the laws of writing, whose creative logic often runs counter to the doxa, to the point of betraying even the empirical author's avowed certainties. Actually, the subversive quality of The Last of the Mohicans 
probably lies in and reflects the nation's ambivalence: as the Frontier was receding, the cost of the "civilizing" process was perceived (at least by some) as very high. The wilderness was being destroyed ("Natur' is sadly abused by man", Cooper 2008: 139), the Natives were being deported and massacred, and the era was tolling the knell of the die-hard individualists who had been instrumental in the conquest: the most famous historical figure is probably Daniel Boone, and the scout is the closest we may find in The Last of the Mohicans. He is the one that Slotkin considers as the embodiment of Cooper's fictitious aristocratic ideal: "If the military aristocrat is the ideological solution to the contradiction between Jacksonian democracy and social class order, Leatherstocking is the mythic resolution" (1985: 105).

\subsection{A nostalgic ambivalence}

Monuments, especially war monuments, tend to commemorate a traumatic moment. They celebrate the broken harmony that was before and are directly linked to nostalgia, which Jankélévitch defines as "dreamy indulgence towards the past".

The Last of the Mohicans features monuments which go unnoticed by most people and are bound to disappear as memorials as the few who know their existence meet their own death. Such is the case in the forest, as the escaping party find themselves on a battlefield known only to Chingachgook and the scout. The white man once fought the Mohawks there, and the situation leads to an unexpected comic scene:

'I buried the dead with my own hands, under that very little hillock where you have placed yourselves; and no bad seat does it make neither, though it be raised by the bones of mortal men.'

Heyward and the sisters arose, on the instant from the grassy sepulcher; nor could the two latter, notwithstanding the terrific scenes they had so recently passed through, entirely suppress an emotion of natural horror, when they found themselves in such familiar contact with the grave of the dead Mohawks. (Cooper 2008: 143-4)

Without the scout's explanation, the natural surroundings would completely absorb the burial ground into the scenery, and it would be just as if the events had never taken place.

The whole forest may be thought to contain many such unnoticeable memorials, which acquire gothic status: "Such memorials of the passage and struggles of man are yet frequent throughout the broad barrier of wilderness, which once separated the

9 "la complaisance rêveuse à légard du passé". (Jankélévitch 1983: 274, my translation) 
hostile provinces, and form a species of ruins, that are intimately associated with the recollections of colonial history, and which are in appropriate keeping with the gloomy character of the surrounding scenery" (Cooper 2008: 142). The natural environment itself conveys a temple-like atmosphere, as if the forest were some kind of physical and spiritual gateway to the mysteries of death: "The gray light, the gloomy little area of dark grass, surrounded by its border of brush, beyond which the pines rose, in breathing silence, apparently into the very clouds, and the death-like stillness of the vast forest, were all in unison to deepen such a sensation" (Cooper 2008: 144). Thus mythologized, the past is made of death and horror; the celebrated wilderness is also a huge cemetery, as exemplifies the pond whose terrifying story is related by the scout: " "that sheet of dull and dreary water, then, is the sepulchre of the brave men who fell in the contest! [...] When all was over, the dead, and some say the dying, were cast into that little pond. These eyes have seen its waters colored with blood, as natural water never yet flowed from the bowels of the "arth'" (Cooper 2008: 153, 154).

The Last of the Mohicans is born out of a poetic compulsion to recreate the American past beyond that of the mid-eighteenth century, to that of the bygone Mohican and Delaware glory. The romance is deeply rooted in nostalgia, whose etymology ("nostos": "return home" and "algos": "pain") prompts Jankélévitch to put forward a theory that proves instrumental in Cooper's mythopoesis. To the philosopher, nostalgia has to do with the pain of regretting a past that is "irreversible" (impossible to recover), and with the glimpse of the possibility of a solution (going back to the past). Jankélévitch establishes a fundamental difference between the "irreversible" and the "irrevocable" $"$. Irreversibility lies in the nature of time: the past is behind and man is doomed to live in a future-oriented universe. All that happens in time is irrevocable, but an individual tends to notice the irrevocable only in exceptional occasions: "the insoluble problem of the irreversible is the impossibility to relive what has been lived [...]. [T] he insoluble problem of the irrevocable is to undo what has been done"11. By showing a glimpse of an idealized past, The Last of the Mohicans makes the latter desirable.

\section{Conclusion}

After the fashion of Mark Twain, many critics have lamented over and even made fun of Cooper's style. To Fiedler, for instance, "his collected works are monumental in their cumulative dullness" (1960: 180). Notwithstanding the humor, The Last of the Mohicans is a native monument to a lost Adamic time: "[the scout] and the constellation

\footnotetext{
${ }^{10}$ See Jankélévitch 1983: 280.

11 "l'insoluble problème de l'irréversible est l'impossibilité de revivre le vécu [...], l'insoluble problème de l'irrévocable est de défaire l’avoir-fait”. (Jankélévitch 1983: 281, my translation)
} 
of values he represents are doomed to follow the Last of the Mohicans into exile and extinction" (Slotkin 1985: 105). Its purpose is also didactic: since this idealized past is shown to have disappeared through the fault of the white man, it is logical for the white - implied reader of that time to want to recover that past, to regret the historical mistakes, and maybe to wish they had never taken place.

1826 was far from 1757, yet close enough so that readers could still feel part of the same destructive process, notably due to the ruthless military operations of Indian removal that were going on. Cooper's romance, then, partakes of two trends inherent to the nostalgic impulse: on the one hand aesthetic contemplation, connected with the "irreversible" and, on the other, moral torture, entailed by the utter impossibility to undo the past, in harmony with the "irrevocable".

Though universal in itself, nostalgia in The Last of the Mohicans still aptly crystallizes the American predicament. Built upon a dream with a religious basis, the new Promised Land soon had to face a contemporary reality that was not so different from that of Europe. Its cruel treatment of the Natives, for instance, might be seen as a mirror image of the European oppression that prompted the exodus of the Pilgrims. In many ways, The Last of the Mohicans presents a veiled celebration of blurred social and racial lines; in 1826, time was already ripe for fantasizing the not so distant national beginnings. Coherent as such a psychological process may appear, it still lies on a fundamentally irrational logic: "What is regretted here is not what is regrettable (for they may not be anything to regret); it is the arbitrary, unreasonable and even irrational fact of pastness in itself"'

\section{References}

Blakemore, S. (1997). 'Without a Cross': The Cultural Significance of the Sublime and Beautiful in Cooper's The Last of the Mohicans. Nineteenth-Century Literature, 52, June 1997, 27-57.

Cooper, J. F. (1826, 2008). The Last of the Mohicans. Oxford and New York: Oxford University Press.

Dekker, G. (1987). The American Historical Romance. Cambridge: Cambridge University Press.

Fiedler, L. (1960, 2003). Love and Death in the American Novel. Champaign: Dalkey Archive.

\footnotetext{
12 "Ce n'est pas le regrettable qui est ici regretté (car il n’y a peut-être rien à regretter), c'est le fait arbitraire, déraisonnable, et même irrationnel de la passéité en soi”. (Jankélévitch 1983: 353, my translation)
} 
Genette, G. (1987, 1997). Paratexts: Thresholds of Interpretation. Cambridge: Press Syndicate of the University of Cambridge.

Jankélévitch, V. (1983). L'irréversible et la nostalgie. Paris: Flammarion.

Lukacs, G. (1962). The Historical Novel. London: Merlin Press.

Lukacs, G. (1971). The Theory of the Novel. London: Merlin Press.

Porte, J. (1969). The Romance in America: Studies on Cooper, Poe, Hawthorne, Melville and James. Middletown, Conn.: Wesleyan University Press.

Rans, G. (1991). Cooper's Leather-Stocking Novels: A Secular Reading. Chapel Hill: University of North Carolina Press.

Roudeau, C. (2015). Chapitre II. A Name for a Monument: Epitaphs of Native America in James Fenimore Cooper and Lydia Howard Sigourney. In: C. Lanone et al. (eds), Monument et modernité dans l'art et la littérature britanniques et américains, Paris: Presses Sorbonne Nouvelle, 39-56. (1 April 2018) <https:// books.openedition.org/psn/732039-56>.

Slotkin, R. $(1985,1998)$. The Fatal Environment: The Myth of the Frontier in the Age of Industrialization, 1800-1890. Norman: University of Oklahoma Press.

Twain, M. (1895, 2012). Fenimore Cooper's Literary Offenses. Mark Twain in His Times: Twain's Indians. University of Virginia Library. (1 April 2018) <http:// twain.lib.virginia.edu/projects/rissetto/offense.html>. 